\title{
ANALISIS EFEKTIFITAS PENCAIRAN DANA PADA DI PEMERINTAH DAERAH: KAJIAN EMPIRIS DI PROVINSI PAPUA BARAT
}

\author{
Emiliana Antonina Kadmaer \\ trikora20@gmail.com
}

\begin{abstract}
Abstrak
This study intends to examine the importance of supervision, standard operating procedures (SOP) and quality of human resources on the effectiveness of funds disbursement in a local government. The researcher used the context and environment of the West Papua Province as a research case. The research used full samples by spreading questionnaires to all treasurer in charge of disbursing funds. The study analyzes data in a descriptive and quantitative with multiple regression tools. Our results explain that there is an influence of supervision, SOP and the quality of human resources on the effectiveness of funds disbursement. Such impacts occur partially and simultaneously.
\end{abstract}

Keywords: supervision, standard operating procedures, human resources, effectiveness, funds disbursement

\section{PENDAHULUAN}

Pencairan dana merupakan salah layanan pemerintah daerah yang pelaksanaannya seringkali kurang efektif (Blegur, Irianto, dan Rosidi, 2017; Parera, Kalangi, dan Budiarso, 2019). Berulang diberitakan media bahwa pencairan dana yang terlambat akan mengganggu pelaksanaan program dan kegiatan. Bahkan ada di sejumlah daerah kegiatan yang tidak dilaksanakan karena dana lambat dicairkan (Herawati, 2014; Salle, 2019). Di akhir tahun kegiatan bertumpuk karena masalah proses pencairan dana lambat diproses. Bantuan social yang mendesak diberikan dalam masa bencana berulang terkendala karena pencairan dana. Pencairan dana merupakan proses atau tahapan yang dilaksanakan untuk mencairkan dana dari kas daerah (KASDA) yang dibuktikan dengan penerbitan Surat Perintah Pencairan Dana (SP2D) Hayadi (2013). Peraturan Menteri Dalam Negeri Nomor 59 Tahun 2007 menjelaskan proses pencairan dana melalui tahapan: pembuatan Surat Permintaan Pembayaran (SPP), penerbitan Surat Perintah Membayar (SPM), dan yang penerbitan SP2D. Berdasarkan SP2D yang diterbitkan tersebut selanjutnya dikirim ke bank untuk mencairkan dana, yang diterima bendahara pengeluaran. Selanjutnya bendahara pengeluaran akan mengeluarkan dana dan diberikan kepada pelaskana kegiatan. 
Sejak penerbitan SPP perlu waktu sekitar seminggu untuk pencairan dana. Perlu waktu dua hari kerja untuk penerbitan SPM, yaitu sejak pejabat yang berwenang menerima dokumen SPP. Lagi dibutuhkan waktu dua hari kerja untuk penerbitan SP2D sejak diterimanya dokumen SPM. Berdasarkan perhitungan waktu ini, diperlukan maksimal enam hari kerja untuk penerbitan SP2D - yaitu sejak penerbitan SPP. Namun dalam kenyataan, yang terjadi di lapangan ialah waktu penerbitan SP2D ini sering mengalami keterlambatan - dari sisi waktu dapat dinilai tidak efektif.

Ada tiga factor yang diduga berpengaruh terhadap efektifitas pencairan dana penerbitan SP2D. Ketiga factor ini adalah pengawasan, Standard Operating Procedure (SOP) dan kualitas SDM. Faktor pengawasan, khususnya pengawasan dari pimpinan kepada seorang bendahara pengeluaran sangat penting untuk menjaga efektifitas pencairan dana (Akhmad, Mustanir, dan Ramadhan, 2017; Hanafiah, Abdullah, dan Saputra, 2016). Pimpinan Organisasi Perangkat Daerah (OPD) yang kurang memperhatikan pengawasan terdahap bendahara berakibat pada penyalahgunaan dana sehingga bendahara harus menanggung kerugian (Blegur, 2017, Parera, 2019). Studi pentingnya SOP dalam meningkatkan penerbitan SP2D telah diteliti. Studi telah dilakukan oleh Haris (2015) dalam pencairan dana APBN. Studi yang lain oleh Daga dan Renaldy (2019). Peran SDM seperti pendidikan dan pelatihan juga membentuk kapasitas bendahara pengeluaran dalam mengefektifkan pencairan dana (Kapoh, Karamoy, \& Sabijono, 2015).

Berdasarkan fenomena - keterlambatan pencairan dana yang berulang, serta hasil penelitian sebelumnya peneliti bermasud mencari penjelasan empiris tentang faktor penyebab kurang efektifnya proses penerbitan SP2D di pemerintah daerah - dengan menggunakan kasus nyata di Provinsi Papua Barat. Fokus studi mengkaji pengaruh factor pengawasan, SOP dan kualitas SDM terhadap efektivitas pencairan dana. 


\section{LANDASAN TEORI DAN PENGEMBANGAN HIPOTESIS}

\section{New Public Management}

New Public Management (NPM) merupakan konsep penting dalam reformasi sektor publik. Konsep NPM berkaitan erat dengan permasalahan manajemen kinerja seperti yang banyak terjadi di pemerintah daerah. Salah satu masalah manajemen kinerja yang menjadi perhatian dalam penelitian ini pengukuran kinerja. Gerakan NPM pada awalnya terjadi di negara-negara maju di Eropa, akan tetapi pada perkembangannya konsep NPM menjadi suatu gerakan global, sehingga negara-negara berkembang pun menggunakannya dalam pemerintahan - pusat dan daerah.

New Public Management tidak selalu dipahami sama oleh semua orang. Bagi beberapa peneliti, NPM diartikan sebagai suatu system manajemen dengan sejumlah perangkat manajemen baru seperti controlling, benchmarking dan lean management. Pengertian lain NPM dimaknai sebagai privatisasi atau implementasi prinsip business yang rasional dalam aktivitas dan operasional pemerintah. Sebagian lagi penulis mengartikan NPM sebagai perangkat baru pengendalian pemerintah dalam membangun persaingan dan deregulasi untuk penyediaan layanan kepada warga.

Menurut Hood (1991) ada 7 karakteristik New Public Management, yaitu:

1. Hands-on professional management. Pelaksanaan tugas manajemen pemerintahaan diserahkan kepada manajer professional.

2. Explicit standards and measures of performance. Adanya standar dan ukuran kinerja yang jelas.

3. Greater emphasis on out put controls. Lebih ditekankan pada control hasil/keluaran.

4. A shift to desegregations of units in the public sector. Pembagian tugas ke dalam unitunit yang dibawah.

5. A shift to greater competition in the public sector. Ditumbuhkannya persaingan ditubuh sektor publik.

6. A stress on private sectore styles of management practice. Lebih menekankan diterapkannya gaya manajemen sektor privat. 
7. A stress on greater discipline and parsimony in resource use. Lebih menekankan pada kedisiplinan yang tinggi dan tidak boros dalam menggunakan berbagai sumber. Sektor publik seyogjanya bekerja lebih keras dengan sumber-sumber yang terbatas (to do more with less).

Tujuan NPM adalah untuk merubah administrasi publik sedemikian rupa sehingga, kalaupun belum bisa menjadi perusahaan, ia bisa lebih bersifat seperti perusahaan. Administrasi publik sebagai penyedia jasa bagi warga harus sadar akan tugasnya untuk menghasilkan layanan yang efisien dan efektif. Tapi, di lain pihak ia tidak boleh berorientasi pada laba. Padahal ini wajib bagi sebuah perusahaan kalau ia ingin tetap bertahan dalam pasar yang penuh persaingan.

\section{Efektifitas prosedur sistem keuangan}

Prosedur dalam sistem keuangan daerah merupakan langkah-langkah atau tahapan pengerjaan aktivitas keuangan yang bertujuan untuk menjaga efektiftas dan efisiensi aktivitas. Menurut Mulyadi (2008) Prosedur dalam suatu kegiatan melibatkan beberapa orang, dalam satu departemen yang sama atau berbeda, yang megerjakan bagian tertentu dari total kegiatan. Pemisahan bagian kegiatan untuk dikerjakan terpisah oleh beberapa orang merupakan mekanisme pengendalian yang penting, namun dalam pelaksanaannya dapat menjadi sumber masalah bila kurang pengawasan dari pimpinan, kurang pemahaman terhadap SOP, atau rendahnya kualitas atau kompetensi SDM pelaksana. Susanto (2007) Susanto menyatakan bahwa Prosedur adalah rangkaian aktivitas atau kegiatan yang dilakukan secara berulang dengan cara yang sama. Dari pengertian prosedur diatas, maka dapat disimpulkan bahwa pengertian prosedur adalah suatu urutan tugas dan pekerjaan yang saling berhubungan dan dikerjakan berulang dalam rangka pencapaian tujuan kegiatan.

Menurut Ratminto dan winarsih (2005) efektivitas didasari atas tujuan yang ingin dicapai sesuai dengan perencanaan yang telah ada. Kecepatan pelayanan juga merupakan ukuran penting, oleh sebab itu target waktu layanan harus ditetapkan pemberi layanan. 
Suatu kegiatan dinyatakan efektif bila ukuran telah direalisir, yaitu sasaran atau tujuan kegiatan Sedarmayanti (2012).

Efektivitas kerja organisasi sangat tergantung dari efektivitas kerja dari orang-orang yang bekerja didalamnya. Ada beberapa kriteria yang dapat digunakan untuk mengukur efektivitas kerja dari organisasi yang memberikan pelayanan Siagian (1987) yaitu: faktor waktu atau ketepatan waktu dalam layanan (2) faktor kecermatan yaitu ketelitian dan minimnya kesalahan dalam layanan, dan (3) faktor keterbukaan atau kejelasan informasi seperti persyaratan dan tahapan layanan.

Martani dan Lubis (1987) menyebutkan 3 (tiga) pendekatan utama dalam pengukuran efektifitas organisasi, yaitu :

1. Pendekatan sasaran. Pendekatan ini memusatkan perhatiannnya dalam mengukur efektivitas pada aspek output, yaitu dengan mengukur keberhasilan organisasi publik dalam mencapai tingkatan output yang direncanakan. Beberapa sasaran yang dianggap penting dalam kinerja suatu organisasi adalah efektivitas, efisiensi, produktivitas, keuntungan, pengembangan, stabilitas dan kepemimpinan.

2. Pendekatan sumber. Pendekatan ini mengukur efektivitas dari sisi input, yaitu dengan mengukur keberhasilan organisasi publik dalam mendapatkan sumber- sumber yang dibutuhkan. Indikator yang dipergunakan dalam pendekatan ini adalah kemampuan memanfaatkan lingkungan, menginterpretasikan lingkungan, kemampuan memelihara kegiatan organisasi dan kemampuan untuk bereaksi serta menyesuaikan diri dengan lingkungan.

3. Pendekatan proses. Pendekatan ini menekankan pada aspek internal organisasi publik, yaitu dengan melihat sejauh mana efektivitas pelaksanaan program dari semua kegiatan proses internal atau mekanisme organisasi. Indikator yang digunakan adalah prosedur pelayanan, sarana dan prasarana, semangat kerjasama dan loyalitas kelompok kerja.

Dari ketiga pendekatan tersebut dapat dikemukakan bahwa efektivitas organisasi merupakan suatu konsep yang mampu memberikan gambaran tentang keberhasilan suatu organisasi dalam mencapai sasarannya. Pada penelitian ini penulis menggunakan 
pendekatan proses untuk mengukur efektivitas pelayanan penerbitan SP2D Pemda Provinsi Papua Barat.

\section{Prosedur penerbitan SP2D}

Prosedur penerbitan SP2D menurut Peraturan Direktur Jenderal Perbendaharaan Nomor PER- 41/ PB/2011 yaitu:

1. Satker mengajukan pendaftaran supplier/kontrak sebagai data awal yang akan digunakan sebagai pelengkap dokumen dalam mengajukan Surat Perintah Membayar (SPM).

2. Petugas (loket) menerima Surat Perintah Membayar (SPM) yang diajukan oleh para Satuan Kerja (Satker).

3. Petugas melakukan konversi atas SPM yang diajukan oleh satker sebelum masuk ke aplikasi SPAN.

4. Melakukan pengujian atas kebenaran dan kelengkapan dokumen oleh petugas konversi, serta melakukan pengecekan atas ketersediaan dana. Apabila ternyata SPM yang diajukan lebih dari Rp 500.000.000 hingga tidak terbatas, maka SPM tersebut harus diajukan kembali 5 hari setelah pengajuan SPM yang pertama, karena untuk memastikan ketersediaan dana oleh Pusat.

5. Setelah petugas melakukan konversi, maka SPM segera diteruskan ke petugas validasi (validator) sebagai Front Office (FO) yang sudah terhubung oleh SPAN untuk dilakukan pemilihan Bank Operasional sesuai yang tertera pada SPM.

6. Dari FO kemudian diteruskan ke fungsi Middle Office $(\mathrm{MO})$ atau petugas approver untuk dilakukan pengecekan ulang atas dokumen. Jika sudah sesuai maka akan disetujui/dilakukan approved.

7. Kemudian dilanjutkan ke fungsi Back Office (BO) yaitu Kepala Seksi Pencairan Dana untuk menyetujui atau menolak SPM dari satker.

8. Setelah ada persetujuan maka akan dikembalikan ke MO untuk dilakukan pencetakan SPPT (Surat Perintah Pembayaran Tagihan) rangkap 2. Namun jika terdapat 
penolakan, SPM akan dikembalikan kepada satker paling lambat 1 hari setelah SPM diajukan.

9. Lembar 1 SPPT rangkap 2 yang telah dicetak, disematkan menjadi satu beserta dokumen SPM sedangkan lembar 2 dicatat dan diteruskan ke Seksi Bank.

10. Setelah SPPT diterima oleh Seksi Bank, maka akan segera di approved oleh Kepala Seksi Bank dan dibubuhi stempel untuk dlakukan penerbitan SP2D.

11. Setelah diterbitkan SP2D, maka SP2D tersebut dikirim ke Bank Operasional (BO) yang ditunjuk oleh Pusat untuk dilakukan pencairan dana ke Rekening Satker yang dituju.

\section{Kerangka Pikir}

Pada dasarnya setiap bidang pekerjaan diperlukan sebuah pengawasan untuk penyelesaian suatu pekerjaan. Fungsi pengawasan yang dilakukan dalam penelitian ini dengan menggunakan beberapa indikator yaitu prosedur, standar, ketelitian, pengukuran pekerjaan, dan perbaikan.

Dari fungsi pengawasan tersebut, manusia memegang peranan penting sebagai kunci keberhasilan di setiap bidang pembangunan daerah. Peran manusia atau sumber daya manusia menjadi penting sebab kunci keberhasilan organisasi berada di bawah kendalinya. Pada sisi individu, Tingkat pemahaman manusia ini juga tergantung dari kualitas manusia tersebut. Ukuran dari kualitas individu, dapat dilihat pada tingkat pendidikan, pengalaman kerja dan pelatihan. Selanjutnya, setelah dari fungsi pengawasan, hal yang paling penting adalah individu bekerja secara efektif.

Pada penelitian ini, efektivitas yang digunakan adalah dengan pendekatan proses. Pendekatan proses dapat dijadikan tolak ukur dengan indikator yaitu prosedur kerja, Semangat kerjasama dan loyalitas kelompok kerja, sarana dan prasarana, kecermatan. Untuk menentukan keberhasilan dan keefektifan manusia dalam bekerja, menusia membutuhkan standar operasional prosedur yang harus di pahaminya.

Standar operasional peosedur dalam penelitian ini adalah terpenuhinya aspek-aspek dalam manual prosedur dan telah dijalankan sesuai dengan prosedur yang berlaku. Indikator 
dalam standar operasional prosedur ini adalah cara melakukan pekerjaan, waktu pelaksanaan, pemahaman pegawai tentang system kerja dan aktor yang berperan dalam kegiatan. Berdasarkan hal tersebut, maka dapat dibuat kerangka pikir seperti di gambar bawah ini.

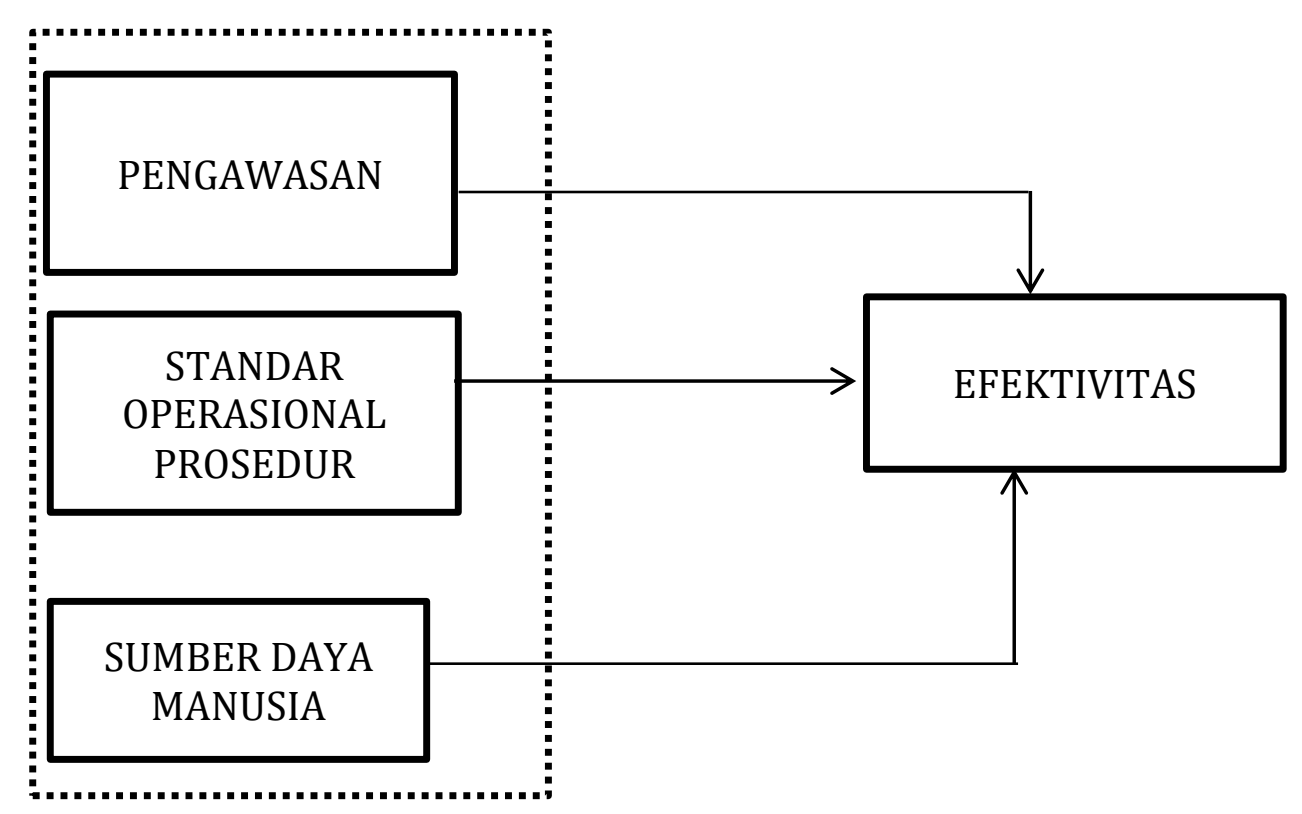

\section{Gambar 1 Kerangka Pikir}

Keterangan:

: Berpengaruh secara parsial

\section{Hipotesa penelitian}

Berdasarkan pendapat Koontz dan Cyril O’Donnel yang dikutip dalam Hasibuan (2014) salah satu prinsip pengawasan adalah pengawasan harus ditunjukan ke arah tercapainya tujuan, yaitu dengan mengadakan perbaikan (koreksi) untuk menghindari penyimpanganpenyimpangan atau deviasi perencanaan. Dengan demikian dapat diajukan hipotesa sebagai berikut:

$\mathrm{H} 1$ : Pengawasan berpengaruh secara parsial terhadap efektifitas

SOP atau standar operasional prosedur adalah dokumen yang berisi serangkaian instruksi tertulis yang dibakukan mengenai berbagai proses penyelenggaraan administrasi 
perkantoran yang berisi cara melakukan pekerjaan, waktu pelaksanaan, tempat penyelenggaraan dan aktor yang berperan dalam kegiatan Insani (2010). Berangkat dari permasalahan dan tujuan penelitian serta ditinjau dari landasan teori, maka diajukan hipotesis kedua sebagai berikut:

H2 : Standar Operasional Prosedur berpengaruh secara parsial terhadap efektifitas Nawawi (2005) manajemen sumber daya manusia adalah mendayagunakan manusia sebagai tenaga kerja secara manusiawi agar otensi fisik dan psikis yang dimilikinya berfungsi maksimal bagi pencapaian tujuan organisasi

H3 : Sumber Daya Manusia berpengaruh secara parsial terhadap efektifitas

Untuk menjawab hipotesis ke empat, berdasarkan pendapat para ahli di atas dan berdasarkan hasil penelitian terdahulu yaitu Kusumaningsih (2016) dan Bustan (2007), maka dapat dibuat hipotesis keempat sebagai berikut.

H4 : Pengawasan, Standar Operasional Prosedur dan Sumber Daya Manusia berpengaruh secara simultan terhadap efektifitas.

\section{METODE PENELITIAN}

Penelitian ini berlokasi di Pemerintah Daerah Provinsi Papua Barat dan unit analisisnya pada masing-masing bendahara pada Organisasi Perangkat Daerah di Lingkungan Pemda Provinsi Papua Barat. Lama Penelitian dilakukan sejak bulan Mei 2019 sampai dengan Juni 2019.

Jenis data yang digunakan dalam penelitian ini adalah data primer dan data sekunder. Data primer diperoleh langsung dari hasil penyebaran kuesioner dan wawancara langsung dengan responden. Kuesioner yang digunakan untuk pengumpulan data dengan menggunakan skala Likert. Menurut Hasan (2002), Variabel penelitian yang diukur dengan skala Likert ini, dijabarkan menjadi dalam indikator variabel yang kemudian dijadikan sebagai titik tolak penyusunan item-item instrumen, bisa berbentuk pernyataan atau pertanyaan. Jawaban setiap item instrumen ini memiliki gradasi dari tertinggi ( sangat 
positif ) sampai pada terendah (sangat negatif). Untuk keperluan analisis secara kuantitatif maka jawaban-jawaban tersebut diberi skor :

- Jawaban sangat memuaskan diberi bobot 4

- Jawaban memuaskan diberi bobot 3,

- Jawaban kurang memuaskan diberi bobot 2,

- Jawaban tidak memuaskan diberi bobot 1 ,

Pada penelitian ini peneliti menghilangkan jawaban netral untuk mengantisipasi kecenderungan responden menjawab pada opsi netral. Hal ini akan berdampak bagi peneliti untuk memperoleh informasi yang digali dari setiap jawaban responden.

Subjek dalam penelitian ini adalah Pejabat Penatausahaan Keuangan dan Para Bendahara di lingkungan OPD Pemda Provinsi Papua Barat dan objek penelitian adalah penerbitan SP2D.

Metode yang digunakan adalah metode Nonprobability sampling dengan teknik sampling jenuh, yaitu pengambilan semua anggota dari populasi yang dilakukan untuk dijadikan sampel. Populasi dalam penelitian ini adalah sebanyak 84 responden pada OPD/SKPD Pemda Provinsi Papua Barat sehingga yang dijadikan sampel semua anggota populasi yaitu 84 responden.

Data sekunder yaitu data yang diperoleh dari bahan kepustakaan seperti laporan pemerintah daerah.

Penelitian ini merupakan penelitian deskriptif kuantitatif yang dilakukan untuk menggambarkan permasalahan yang diteliti serta mengintegrasikan data yang ada secara objektif. Untuk memperkuat dan memperdalam hasil yang diperoleh dari angket tersebut. Jawaban responden tersebut disajikan dalam bentuk tabel tunggal melalui perhitungan distribusi frekuensi dan presentase.

Analisis data yang digunakan peneliti dalam penelitian ini adalah analisis regresi linear beganda. Regresi linear berganda digunakan untuk mengukur kekuatan hubungan antara variabel atau lebih juga menunjukkan arah hubungan antara variabel dependen 
dengan variabel independen Ghozali (2006). Persamaan regresi linear berganda yang digunakan adalah sebagai berikut:

$Y=\alpha+\beta 1 X 1+\beta 2 X 2+\beta 3 \times 3+e$

Dimana :

$\mathrm{Y} \quad=$ Variabel Efektifitas

$\alpha \quad=$ Konstanta

$\beta 1=$ Koefisien dari variabel Pengawasan

$\beta 2=$ Koefisien dari variabel SOP

$\beta 3=$ Koefisien dari variabel Sumber Daya Manusia

$\mathrm{X} 1=$ Variabel Pengawasan

$\mathrm{X} 2=$ Variabel SOP

X3 = Variabel Sumber Daya Manusia

e $\quad=$ Standar Error

\section{HASIL PENELITIAN DAN PEMBAHASAN}

\section{Karakteristik Responden}

Responden berdasarkan tingkat pendidikan dapat dilihat pada Tabel 1 dibawah ini.

Tabel 2

Karakteristik Responden Berdasarkan Tingkat Pendidikan

\begin{tabular}{|l|c|c|}
\hline Tingkat Pendidikan & Jumlah(orang) & Persentase \\
\hline Pasca Sarjana & 15 & 17.86 \\
\hline Sarjana (S1) & 50 & 59.52 \\
\hline Sarjana Muda(D1/D2/D3) & 8 & 9.52 \\
\hline SMA dan Sederajat & 11 & 13.10 \\
\hline
\end{tabular}

Pada tabel 1 di atas menjelaskan bahwa jumlah responden yang berpendidikan pasca sarjana sebanyak 15 orang dengan persentase $17,86 \%$, sedangkan sarjana berjumlah 50 orang atau sebesar $59,52 \%$ dan sarjana muda sebanyak 8 orang atau $9,52 \%$ dan SMA sederajat berjumlah 11 orang atau $13,10 \%$. Jika membaca karakteristik responden tersebut, maka secara kuantitas dan kualitas menunjukkan bahwa tingkat sumber daya manusia sudah baik. Namun, mengingat masih ada pegawai yang berpendidikan SMA sederajat, maka perlu menjadi pehatian masing-masing organisasi peangkat daerah untuk meningkatkan kualitas sumber daya manusianya. 
Lama bekerja merupakan bagian dari suatu karakteristik responden yang penting. Dengan diketahuinya lama bekerja, akan dapat menentukan kompetensi dan pengalaman dalam menghadapi permasalahan dalam pekerjaan. Berikut ini adalah sebaran kuesioner berdasarkaan lamanya bekerja.

Tabel 2

Karakteristik Responden Berdasarkan Lama Bekerja

\begin{tabular}{|c|c|c|c|}
\hline Uraian & $1-4$ tahun & $5-10$ tahun & $>10$ tahun \\
\hline Jumlah & 5 & 41 & 38 \\
\hline Persen $(\%)$ & 5.95 & 48.81 & 45.24 \\
\hline
\end{tabular}

Dari table 2 di atas dapat dijelaskan bahwa mayoritas responden telah bekerja antara 5-10 tahun sebanyak $48,81 \%$ dan di atas 10 tahun sebanyak $45,24 \%$, sedangkan yang bekerja 1-4 tahun sebanyak 5,95\%. Berdasarkan kriteria tersebut, Nampak bahwa responden memiliki pengalaman dalam melaksanakan pekerjaan.

Karakteristik responden berdasarkan usia secara umum dapat dilihat pada table 3 di bawah ini. Usia menunjukkan kematangan dan kedewasaaan dalam bekerja dan dalam menghadapi permasalahan dalam pekerjaan. Tabel di bawah ini menunjukkan karakteristik responden berdasarkan usia dengan persentase.

Tabel 3

Karakteristik Responden Berdasarkan Usia

\begin{tabular}{|c|c|c|}
\hline Usia & Jumlah (orang) & Persentase \\
\hline $20-30$ tahun & 4 & 4.76 \\
\hline $31-40$ tahun & 47 & 55.95 \\
\hline $41-50$ tahun & 24 & 28.57 \\
\hline$>50$ tahun & 9 & 10.71 \\
\hline
\end{tabular}

Berdasarkan Tabel 3 diatas dapat dilihat bahwa umur responden mayoritas pada rentang 31-40 tahunsebanyak 55,95\%. Kemudian pada rentang 41-50 tahun sebanyak 28,57\%. Di atas 50 tahun sebanyak 10,71\% dan terkahir rentang usia 20-30 tahun sebanyak $4,76 \%$. Hal ini menyatakan bahwa sebagian besar responden memiliki usia yang produktif, karena pada usia dimana orang tersebut dianggap dapat menghasilkan sesuatu bagi tempat dimana orang tersebut akan bekerja. 


\section{Analisis Data}

\section{Variabel efektifitas pelayanan}

Prosedur Pelayanan adalah kemudahan tahapan pelayanan yang diberikan kepada masyarakat dilihat dari sisi kesederhanaan alur pelayanan serta kejelasan persyaratan pelayanan. Prosedur Pelayanan tidak hanya dituntut untuk menciptakan keteraturan tetapi diutamakan untuk memberikan kemudahan dan kejelasan bagi masyaraat yang membutuhkan pelayanan yang baik. Menurut Umar (2000) rentang skala berfungsi untuk mengetahui pada rentang berapa nilai keputusan yang dihasilkan tersebut berada.

Untuk menghitung dan memperoleh kriteria rentang jawaban responden dilakukan dengan cara, nilai jawaban terkecil adalah 1 (satu) dan jawaban tertinggi 4 (empat). Jawaban terendah adalah 84 diperoleh dari 1 x 84 responden, dan jawaban tertinggi adalah 336 . Selanjutnya dilakukan penskalaan, dimana nilai tertinggi dikurangi nilai terndah dibagi empat kelas kriteria, sehingga diperoleh rentang kriteria adalah 63.

Berdasarkan jumlah jawaban responden sebanyak 84 orang, maka dapat ditentukan kriteria tingkat efektivitas pelayanan seperti terlihat pada table 4.7 di bawah ini.

Tabel 4

Frekuensi Kriteria Efektifitas

\begin{tabular}{|c|c|c|c|}
\hline Rentang Kriteria & Kriteria & Frekuensi $(\mathrm{F})$ & Persentase \\
\hline $84-147$ & STS & 16 & 2.19 \\
\hline $148-210$ & TS & 158 & 21.67 \\
\hline $212-273$ & $S$ & 287 & 39.37 \\
\hline $276-336$ & SS & 268 & 36.76 \\
\hline & Jumlah & 729 & 100 \\
\hline
\end{tabular}

Dari data tabel 4 di atas, Nampak bahwa mayoritas responden menjawab pada kategori setuju sebesar $39,37 \%$ dan sangat setuju sebesar $36,76 \%$. Untuk responden yang menyatakan ketidak setujuan dengan efektifitas sebesar 2,19\% menjawab sangat tidak setuju dan sebesar $21,67 \%$ menjawab tidak setuju. Hasil ini menunjukkan bahwa efektifitas pelayanan dengan indicator prosedur pelayanan, sarana dan prasarana teknologi yang digunakan serta tanggung jawab pegawai dalam pelaksanaan pekerjaan sudah berjalan 
dengan baik. Namun perlu mendapat perhatian dari pimpinan organisasi perangkat daerah, bahwa masih terdapat responden yang menyatakan ketidaksetujuannya $23,86 \%$.

Berdasarkan wawancara dengan responden pegawai yang menyatakan ketidaksetujuan tersebut menyatakan masih banyaknya petugas verifikator yang tidak beada di tempat pada saat di butuhkan dengan berbagai alasan seperti dinas keluar kota dan kurang disiplinnya pegawai dalam melaksanakan pekerjaan.

Menurut para responden, apabila tidak selalu di tempat maka jika terjadi kesalahan dokumen tidak langsung di kembalikan dan tidak dapat di konfirmasi ke yang bersangkutan. Selain itu, masih terdapat pegawai yang masih melakukan kesalahan atau kurang teliti dalam melaksanakan pekerjaan sehingga dapat menghambat pencairan SP2D.

\section{Variabel pengawasan}

Pengawasan dibutuhkan dalam setiap proses dalam tahapan-tahapan dari penerimaan berkas sampai dengan out put yang dihasilkan. Pengawasan yang berjenjang, pemantauan oleh pimpinan, waktu penyelesaian berkas sampai dengan koreksi dan evaluasi yang dilakukan adalah indicator yang digunakan alam penelitian ini.

Berikut ini adalah hasil analisis deskriptif dari 6 pernyataan yang didapat melalui data yang dikumpulkan dari total 84 responden.

Tabel 5

Frekuensi Kriteria Pengawasan

\begin{tabular}{|c|c|c|c|}
\hline Rentang Kriteria & Kriteria & Frekuensi $(F)$ & Persentase \\
\hline $84-147$ & STS & 17 & 3.48 \\
\hline $148-210$ & TS & 143 & 29.24 \\
\hline $212-273$ & S & 186 & 38.04 \\
\hline $276-336$ & SS & 143 & 29.24 \\
\hline \multicolumn{2}{|c|}{ Jumlah } & 489 & 100 \\
\hline
\end{tabular}

Dari data di atas menunjukkan bahwa mayoritas responden menyatakan kesetujuannya terhadap pengawsan yang dilakukan. Responden yang menyatakan sangat tidak setuju sebesar $3,48 \%$, responden yang menyatakan tidak setuju sebesar $29,24 \%$, 
responden yang menyatakan setuju sebesar $38,04 \%$ dan yang menyatakan sangat setuju sebesar $29,24 \%$. Jika melihat table di atas, masih terdapatnya responden yang menyatakan ketidak setujuannya, hal ini menunjukkan masih ada pengawasan yang belum optimal dilakukan.

Berdasarkan wawancara yang dilakukan terhadap responden yang menyatakan ketidaksetujuannya adalah masih kurang telitinya pengawasa dalam meneliti berkas yang diajukan dan waktu penyelesaian pekerjaan menjadi terhambat. Dari beberapa responden yang dilakukan wawancara yang menyatakan ketidak setujuan tersebut mengatakan evaluasi terhadap pekerjaan jarang dilakukan, terutama evaluasi akhir tahun terhadap pekerjaan mereka.

\section{Variabel standar operasional prosedur}

Pada dasarnya Standar Operasional Prosedur (SOP) adalah dokumen yang berkaitan dengan prosedur yang dilakukan secara kronologis untuk menyelesaikan suatu pekerjaan. Berikut ini adalah hasil analisis deskriptif dari 5 pernyataan yang didapat melalui data yang dikumpulkan dari total 84 responden

Tabel 6

Frekuensi Kriteria SOP

\begin{tabular}{|c|c|c|c|}
\hline Rentang Kriteria & Kriteria & Frekuensi $(F)$ & Persentase \\
\hline $84-147$ & STS & 24 & 5.93 \\
\hline $148-210$ & TS & 103 & 25.43 \\
\hline $212-273$ & S & 150 & 37.04 \\
\hline $276-336$ & SS & 128 & 31.60 \\
\hline \multicolumn{2}{|c|}{ Jumlah } & 405 & 100 \\
\hline
\end{tabular}

Dari data di atas menunjukkan bahwa mayoritas pegawai sudah melaksanakan pekerjaan sesuai dengan SOP yang berlaku. Responden yang menyatakan keseujuannya bekerja dengan SOP dengan berpendapat setuju sebanyak $37 \%, 04$ dan sangat setuju sebanyak 31,6 \%. Namun masih terdapat reponden yang menyatakan ketidak setujuan 
dalam melaksanakan pekerjaan dengan SOP sebanyak 5,93\% menyatakan sangat tidak setuju dan 25,43 \% menyatakan tidak setuju. Berdasarkan wawancara terhadap para rresponden tersebut, banyak responden yang merasa belum memahami system pekerjaan.

Selain itu, responden menyatakan bahwa dokumen sering tidak sesuai dengan SOP, dan yang paling utama adalah menurut responden SOP tidak update dengan peraturanperaturan terbaru termasuk jenis-jenis pembayaran yang ada. Repsonden pada dasarnya menginginkan SOP dalam hal bekerja, namun responden menginginkan selalu di updatenya peratuan-perauran terbaru dan menginginkan satu kesepahmn dalam teknis pelaksanaan pekerjaan.

\section{Variabel sumber daya manusia}

Sumber daya manusia memiliki peran penting dalam setiap organisasi. Kemajuan suatu organisasi tergantung dari kualitas sumber daya manusia tersebut. Ukuran dari kualitas individu, dapat dilihat pada tingkat pendidikan,pengalaman kerja dan pelatihan. Berikut ini adalah hasil analisis deskriptif dari 6 pernyataan yang didapat melalui data yang dikumpulkan dari total 84 responden.

Tabel 7

Frekuensi Kriteria Sumber Daya Manusia

\begin{tabular}{|c|c|c|c|}
\hline Rentang Kriteria & Kriteria & Frekuensi $(\mathrm{F})$ & Persentase \\
\hline $84-147$ & STS & 28 & 5.73 \\
\hline $148-210$ & TS & 147 & 30.06 \\
\hline $212-273$ & S & 146 & 29.86 \\
\hline $276-336$ & SS & 168 & 34.36 \\
\hline
\end{tabular}

Dari data di atas Nampak bahwa peran sumber daya manusia menjadi kunci utama dalam pelaksanaan pekerjaan. Mayoritas responden menjawab sangat setuju sebanyak $34 \%$ dan menyatakan setuju sebanyak 29,86 persen. Namun masih ada responden yang menjawab 30,06\% tidak setuju dan 5,73 menyatakan sangat tidak setuju. Ketidak setujuan yang cukup signifikan tersebut berdasarkn pengamatan dan wawancara peneliti, masih terdapat pegawai yang tidak sesuai dengan bidangnya dalam bekerja sehingga mereka 
kurang memahami tugas dan fungsinya dalam penatausahaan keuangan daerah. Kurang pahamnya pegawai disebabkan oleh kurangnya kompetensi yang dimiliki.

Para pegawai yang menjadi responden menginginkan pendidikan dan pelatihan sehingga mereka memiliki kompetensi dalam pelaksanaan pekerjaan. Pendidikan dan pelatihan ini dimaksudkan untuk mengantisipasi jika ada peraturan-peraturan baru dan system informasi yang berbeda atau berubah.

\section{Pengujian hipotesa penelitian}

Linier Berganda digunakan untuk mengukur kekuatan hubungan antara dua variabel atau lebih juga menunjukan arah hubungan antara variabel dependen dengan variabel independen Ghozali (2006).

Tabel 8

Nilai Koefisien Hubungan Antar Variabel

\begin{tabular}{|c|c|c|c|c|c|c|}
\hline & \multirow[t]{2}{*}{ Model } & \multicolumn{2}{|c|}{$\begin{array}{c}\text { Unstandardized } \\
\text { Coefficients }\end{array}$} & \multirow{2}{*}{$\begin{array}{c}\text { Standardized } \\
\text { Coefficients } \\
\text { Beta }\end{array}$} & \multirow[t]{2}{*}{$t$} & \multirow[t]{2}{*}{ Sig. } \\
\hline & & $B$ & Std. Error & & & \\
\hline \multirow{4}{*}{1} & (Constant) & 14.810 & 2.790 & & 5.308 & .000 \\
\hline & $\begin{array}{c}\text { PENGAWASA } \\
\mathrm{N}\end{array}$ & .286 & .138 & .223 & 2.074 & .041 \\
\hline & SOP & .314 & .146 & .236 & 2.157 & .034 \\
\hline & SDM & .204 & .098 & 210 & 2.079 & .041 \\
\hline
\end{tabular}

a. Dependent Variable: EFEKTIVITAS

Berdarkan Tabel 8 diatas, dapat diperoleh bentuk persamaan regresi sebagai berikut:

Efektivitas Pencairan Dana $=14,810+$ 0,286 Pengawasan + 0,314 SOP + 0,204 SDM

Untuk menguji hipotesis secara simultan dapat dilihat pada nilai $F$ dan untuk uji parsial dilakukan dengan uji $\mathrm{t}$ atau melihat signifikansi pada kolom koefisien. Uji $\mathrm{t}$ menunjukan seberapa jauh pengaruh satu variabel penjelas/ independen secara individual dalam menerangkan variasi variabel dependen (Ghozali, 2006).

a) Jika thitung $>t$ tabel, atau nilai signifikan $\mathrm{t}<0,05$ maka $\mathrm{H}_{0}$ tolak dan $\mathrm{H}_{\mathrm{a}}$ diterima.

b) Jika t hitung $<\mathrm{t}$ tabel, atau nilai signifikan $\mathrm{t}>0,05$ maka $\mathrm{H}_{0}$ diterima dan $\mathrm{H}_{\mathrm{a}}$ ditolak. 
Dengan menggunakan kriteria ini dapat dijelaskan

H1 : Pengawasan berpengaruh secara parsial terhadap efektifitas

Berdasarkan nilai cut off di atas, maka berdasarkan table 4.12, hipotesa pertama dapat disimpulkan bahwa, pengawasan berpengaruh secara parsial terhadap efektivitas pelayanan karena nilai signifikansi 0,041 lebih kecil dari 0,05 $(0,041<0,05)$.

H2: Standar Operasional Prosedur Berpengaruh Secara Parsial Terhadap Efektifitas

Dengan menggunakan nilai cutoff sig > 0,05 maka menerima Ho dan menolak $\mathrm{H} 1$, dan jika sig $<0,05$ menolak Ho dan menerima H1. Dengan mengacu nilai cut off tersebut, maka berdasarkan table 4.12, hipotesa kedua dapat disimpulkan bahwa standar opersional prosedur berpengaruh secara parsial terhadap efektivitas pelayanan dan menerima $\mathrm{H} 2$ karena nilai signifikansi 0,034 lebih kecil dari $0,05(0,034<0,05)$.

\section{H3 : Sumber Daya Manusia Berpengaruh Secara Parsial Terhadap Efektifitas}

Dengan menggunakan nilai cutoff sig > 0,05 maka menerima Ho dan menolak $\mathrm{H} 1$, dan jika sig $<0,05$ menolak Ho dan menerima H1. Dengan mengacu nilai cut off tersebut, maka berdasarkan table 4.12, hipotesa ketiga dapat disimpulkan bahwa sumber daya manusia berpengaruh secara parsial terhadap efektivitas pelayanan menerima $\mathrm{H} 2$ karena nilai signifikansi 0,041 lebih kecil dari 0,05 $(0,041<0,05)$

H4: Pengawasan, Standar Operasional Prosedur Dan Sumber Daya Manusia Berpengaruh Secara Simultan Terhadap Efektifitas

Untuk menguji secara simultan Pengawasan, Standar Operasional Prosedur dan Sumber Daya Manusia berpengaruh secara simultan terhadap efektifitas dapat mengunakan table 4.13 di bawah ini. Nilai cut of jika nilai sig $<0,05$ menerima h1, namun sebaliknya jika nilai sig > 0,05 maka menerima Ho.

\section{Pembahasan}

Tujuan penelitian ini adalah untuk menguji dan menganalisis bahwa secara parsial Pengawasan berpengaruh terhadap efektifitas. Selanjutnya dilakukan pengujian hipotesis dan menganalisis bahwa pengawasan berpengaruh terhadap efektivitas. 
Telah di jelaskan sebelumnya pada uji hipotesis, bahwa pada hipotesa pertama pengawasan berpengaruh secara parsial terhadap efektivitas pelayanan. Pengawasan berpengaruh secara parsial terhadap efektivitas pelayanan karena nilai signifikansi 0,041 lebih kecil dari $0,05(0,041<0,05)$. Nilai signifikan dibawah 0,05 menunjukkan bahwa pengawasan menjadi hal penting dalam pelaksanaan pekerjaan. Hasil penelitian ini juga menunjukkan bahwa fungsi pengawasan, dalam pelaksanaan pekerjaan akan memberikan dampak pada efektivitas kerja dan pelayanan kerja dalam penerbitan SP2D di Lingkungan Bendahara Pemda Provinsi Papua Barat. Dengan adanya pengawasan, hal-hal yang berkaitan dengan kesalahan atau penyimpangan dapat segera teratasi. Hal ini sesuai dengan teori yang dikemukakan oleh Koontz dan Cyril O'Donnel yang dikutip dalam Hasibuan (2014) bahwa salah satu prinsip tujuan dari pengawasan adalah untuk menghindari penyimpangan-penyimpangan atau deviasi perencanaan.

Hasil penelitian ini juga sesuai dengan teori yang dikemukakan oleh Handoko (2013) yang menyatakan dengan adanya fungsi pengawasan dilakukan untuk pengukuran kerja dan evaluasi kerja.

Pengawasan yang baik pada tiap-tiap jenjang pekerjaan dari penerimaan berkas sampai dengan diterbikannya SP2D oleh pimpinan di masing-masing organisasi perangkat daerah di Provinsi Papua Barat telah di laksanakan dengan baik. Pengawasan berjenjang yang dimaksud adalah pengawasan yang berkaitan dengan pengendalian, penilaian resiko, kegiatan pengendalian.

Pengendalian berkaitan dengan orang, moralitas, integritas, kejujuran dan kompetensi. Demikian dengan dokumen-dokumen yang digunakan dikelola oleh pihak-pihak terkait sesuai fungsinya seperti pada dokumen SPD dimana Kuasa BUD menyiapkan rancangan SPD kemudian menyerahkan kepada PPKD untuk diotorisasi dan ditandatangani. Kuasa BUD merupakan pihak-pihak yang memiliki integritas dan kompetensi dalam pengelolaan dokumen. Pada dokumen SPP disiapkan oleh Bendahara Pengeluaran untuk kemudian diserahkan kepada PPK-SKPD. PPK-SKPD membuat rancangan SPM setelah 
dokumen SPP dinyatakan lengkap dan menyerahkannya kepada Kuasa BUD untuk kemudian meneliti dokumen SPM. Apabila dokumen SPM dinyatakan lengkap maka Kuasa BUD menerbitkan SP2D.

Pengawasan selanjutnya sebelum SPD diterbitkan dilakukan pengecekan DPASKPD yang dilakukan oleh Kuasa BUD yang disesuaikan juga dengan anggaran kas yang ada. Selanjutnya pada dokumen SPP dilakukan pengecekan oleh PPK-SKPD terhadap dokumen SPP beserta lampirannya menurut jenis dan fungsinya. Selanjutnya untuk dokumen SPM di lakukan pengecekan oleh Kuasa BUD yaitu dengan melihat kesesuaian batasan jumlah berdasarkan DPA-SKPD. Apabila telah dinyatakan lengkap maka Kuasa BUD membuat rancangan SP2D.

Selanjutnya tahapan pengawasan dapat berupa kegiatan pengendalian. Kegiatan pengendalian adalah tindakan yang diperlukan untuk mengatasi resiko serta penetapan dan pelaksanaan kebijakan dan prosedur untuk memastikan bahwa tindakan mengatasi resiko telah dilaksanakan secara efektif. Dokumen-dokumen yang digunakan seperti pada dokumen SPD harus melihat DPA-SKPD dan anggaran kas yang tersedia, biasanya penerbitan SPD dibawah tangal 10 dan dari hasil penelitian SPD yang diajukan kadang untuk dikoreksi karena dokumen yang diajukan lengkap. Selanjutya untuk pengajuan dokumen SPP oleh bendahara pengeluaran dilakukan setelah SPD diterima. Bendahara pengeluaran langsung membuat SPP setelah SPD diterima dan langsung diserahkan kepada PPK-SKPD untuk diperiksa. Bila SPP yang diajukan telah lengkap SPP langsung ditandatangani dan dalam seharipun proses penerbitannya langsung selesai dan hal yang sama juga diterapkan pada dokumen SPM.

Namun di beberapa organisasi perangkat daerah di Provinsi Papua Barat masih terjadi keterlambatan dan belum berjalan efektif meskipun pengawasan telah dilakukan. Faktor-faktor keterlambatan tersebut berupa :

1. Penginputan SPM yang sudah berupa SPM fisik yang diserahkan ke BPKAD belum dilakukan penginputan menjadi SP2D pada waktu penyerahan SPM.

2. Pengantaran SP2D ke Bank untuk dilakukan pembukuan masih lambat. 
3. Verifikator tidak berada di tempat juga merupakan kendala sehingga proses verifikasi terhambat dan masih harus menunggu verifikator menyelesaikannya.

Untuk membahas tujuan penelitian kedua, yaitu menguji dan menganalisis pengaruh Standard Operasional Prosedur secara parsial terhadap efektivitas perlu dijelaskan fungsi dari SOP. SOP adalah tata cara atau prosedur yang harus ditaati oleh pegawai dalam pelaksanaan pekerjaan untuk mengatasi jika terjadi kesalahan teknis atau non teknis segera dapat diatasi. Tata cara tersebut berdasarkan Permendagri No. 59 Tahun 2007 adalah sebagai berikut:

Bendahara Umum Daerah (BUD) bertanggung jawab dalam pembuatan SP2DUP/GU/TU/LS. bendahara pengeluaran SKPD hanya bertugas melengkapi dokumendokumen untuk pencairan dana. Bendahara pengeluaran hanya berperan untuk mencairkan SP2D di bank, namun segala aktivitas pengeluaran kas dicatat kedalam Buku Kas Umum Pengeluaran, Buku pembantu simpanan bank, Buku pembantu pajak Sehingga prosedur setelah dikeluarkannya SP2D di tangan bendahara pengeluaran. Hal ini jika ditinjau menurut Permendagri No. 59 Tahun 2007, terdapat hal-hal yang sesuai sebagai berikut :

1. Setelah diterbitkan SPM oleh PPK-SKPD dan telah ditandatangani oleh pengguna anggaran, bendahara pengeluaran selanjutnya menyerahkan SPM kepada Kuasa BUD untuk diterbitkan Surat Perintah Pencairan Dana (SP2D). Prosedur penerbitan SP2D pada organisasi perangkat daerah menyesuaikan dengan peraturan pemerintah.

2. Kuasa BUD meneliti kelengkapan dokumen SPM yang dilampirkan sekaligus dengan SPD, SPP dan dokumen atau bukti pengeluaran kas lainnya. Prosedur penerbitan SP2D harus sesuai dengan Permendagri No. 59 Tahun 2007 pada Pasal 216.

3. Kuasa BUD kemudian menerbitkan SP2D yang telah ditandatangani oleh PPKD paling lambat 2 hari. Prosedur penerbitan SP2D telah sesuai dengan Permendagri No. 59 Tahun 2007 pada Pasal 217 ayat (1). 
4. Apabila SPM tidak lengkap dikembalikan pada bendahara pengeluaran untuk dilengkapi paling lama 1 hari sejak pengajuan SPM dilakukan.

5. Apabila SP2D dalam bentuk UP/GU/TU maka diserahkan pengguna anggaran, apabila SP2D-LS maka Kuasa BUD menyerahkannya langsung kepada pihak ketiga

Berdasarkan pengamatan dan observasi di lapangan,secara umum permasalahanpermasalahan teknis masih bisa di atasi meski berpengaruh terhadap terlambatnya pembayaran SP2D. Proses keterlambatan tersebut dimulai sejak masuknya tagihan, bendahara pengeluaran semsestinya membuat SPP paling lambat sehari sejak tagihan diterima namun fakta dilapangan menunjukkan bahwa tagihan dibuat lebih dari satu hari. Hal itu disebabkan banyak tagihan yang masuk bersamaan pada hari itu,sehingga terjadi keterlambatan pembuatan SPP. Kemudian PPK terlambat memeriksa SPP karena melakukan perjalanan dinas. Semestinya SPP diperiksa paling lambat 1 hari sejak berkas SPP diterima,tapi pada kenyataannya PPK memeriksa lebih dari satu hari. Hal lain yang perlu mendapat perhatian adalah penerbitan SPM. Sesuai ketentuan proses penerbitan SP2D paling lambat 2 hari sejak diterimanya dokumen SPM. Dan pada kenyataannya Kuasa BUD baru bisa menerbitkan SP2D lebih dari dua hari.

Untuk mengantisipasi permasalahan yang berulang, pimpinan organisasi perangkat daerah harus melaksanakan SOP dan guna mereduksi kesalahan-kesalahan teknis dan non teknis tersebut. Kesalahan-kesalahan non teknis tersebut pada dasarnya dapat diminimalkan dengan melaksanakan SOP. Penelitian ini menunjukkan bahwa mayoritas para pegawai menginginkan penggunaan SOP dalam pelaksanaan pekerjaan untuk mencapai target. Hal ini sesuai dengan teori yang dikemukakan oleh Hartatik (2014):

Pada penelitian ini ditemukan bahwa, pemahaman dalam pelaksanaan SOP juga perlu mendapat perhatian dari para pimpinan satuan kerja. Peneliti menemukan bahwa masih terdapat para pegawai yang belum memahami system kerja dalam pekerjaan rutin. Selain itu, responden menyatakan bahwa dokumen yang diserahkan sering tidak sesuai dengan SOP, dan yang paling utama adalah menurut responden SOP tidak diupdate dengan peraturan-peraturan terbaru termasuk jenis-jenis pembayaran yang ada. Untuk itu, para 
unsur pimpinan diharapkan selalu mengupdate informasi-informasi terbaru jika ada perubahan peraturan.

Untuk tujuan ketiga yaitu menguji dan menganalisis kualitas sumber daya manusia, hasil penelitian pengaruh sumber daya manusia terhadap efektivitas pelayanan berpengaruh signifikan. Penggunaan teknologi, pelatihan kepada para bendahara pada penggunaan system dan informasi-informasi terbaru harus selalu di update oleh pimpinan satuan kerja. Namun yang perlu mendapat perhatian, masih terdpatnya responden yang belum memiliki kompetensi di bidang ini karena belum mendapatkan pelatihan penggunaan system dan teknologi yang digunakan. Mereka menginginkan pendidikan dan pelatihan sehingga mereka memiliki kompetensi dalam pelaksanaan pekerjaan. Pada dasarnya para responden ini menyadari bahwa peningkatan kualitas dengan pendidikan dan pelatihan akan meningkatkan kompetensi mereka.

Hasil penelitian ini juga sejalan dengan peneliti sebelumnya yaitu Bustan (2007) yang menyatakan sumberdaya manusia yang mengikuti diklat, dan sarana komputer berpengaruh positif dan signifikan terhadap keterlambatan penerbitan surat perintah pencairan dana. Selain itu penelitian ini juga sejalan dengan Kusumaningsih (2016) yang menyatakan Kualitas Sumber daya Manusia dan teknologi berpengaruh terhadap kualitas SP2D.

Prinsipnya para pegawai dalam melaksanakan pekerjaan harus memiliki kompetensi di bidangnya. Kompetensi di bidangnya in dapat dilihat pada pengalaman kerja yang ratarata pegawai telah cukup lama di atas 5 tahun di bidang yang sama. Salah satu yang menjadi hal positif dalam peningkatan sumber daya manusia, saat ini para pegawai yang menangani penerbitan SP2D mayoritas berpendidikan diploma sampai dengan pasca sarjana. Tingkat pendidikan, pengalaman dan pelatihan yang bepengaruh tehadap efektifitas ini sesuai dengan teori yang dikemukanan oleh Widodo dalam Arfianti (2011)). Dengan meningkatnya tingkat pendidikan dan pelatihan yang ada, diharapkan efektivitas pelayanan dalam penerbitan SP2D oleh bendahara umum daerah dapat berjalan sesuai dengan 
peraturan yang telah ditetapkan yaitu minimal 1 (satu) hari kerja dan maksimal 2 (dua) hari kerja.

Secara simultan variabel pengawasan, standar operasional prosedur dan sumber daya manusia secara positif mempengaruhi efektifitas penciran dana tetapi masih cukup kecil yaitu $23 \%$. Masih banyak factor yang dimungkinkan untuk diteliti dibandingkan dengan model yang diteliti saat ini. Faktor jumlah SDM, jumlah sarana prasarana serta komitmen pada organisasi perangkat daerah masih perlu dibuktikan melalui penelitian lanjutan.

Secara simultan dapat diketahui unsur yang paling dominan dalam pelaksanaan pekerjaan mempengaruhi efektivitas pencairan dana. Lebih dominannya standard operasional prosedur dalam mempengaruhi efektivitas menunjukkan bahwa dalam proses pelaksanaan pekerjaan para pegawai dan seluruh unsur dalam organisasi perangkat daerah harus mengikuti standard operasional prosedur yang dijalankan. Meskipun berdasarkan wawancara masih belum dilaksanakan secara optimal, namun mayoritas organisasi perangkat daerah telah melaksanakan standard operasional prosedur.

\section{SIMPULAN}

Berdasarkan pembahasan maka dapat di tarik kesimpulan sebagai berikut:

1. Pengawasan secara parsial berpengaruh signifikan terhadap efektivitas pelayanan. Pengawasan dapat berupa pengendalian berkaitan dengan orang, moralitas, integritas, kejujuran dan kompetensi dan tindakan yang diperlukan untuk mengatasi resiko serta penetapan dan pelaksanaan kebijakan dan prosedur untuk memastikan bahwa tindakan mengatasi resiko telah dilaksanakan secara efektif. Untuk beberapa organisasi perangkat daerah masih terdapat keterlambatan pencairan karena beberapa alasan seperti verifikator tidak di tempat, dan pengantaran SP2D masih lambat.

2. SOP berpengaruh secara parsial terhadap efektivitas. Hasil penelitian menunjukkan bahwa standar operasional prosedur sudah dilaksanakan namun belum optimal di beberapa organisasi perangkat daerah karena masih terdapat kesalahan dari saat dokumen diterima sampai dengan pencairan dana. 
3. Sumber Daya Manusia berpengaruh secara parsial terhadap efektivitas pencairan dana. Hasil penelitian dapat disimpulkan bahwa dilihat dari tingkat pendidikan, pengalaman dan pelatihan secara kualitas para bendahara sudah baik.

4. Secara simultan Pengawasan, Standard Operasional Prosedur dan Sumber daya manusia berpengaruh terhadap efektivitas pencairan dana, namun pengaruh ini meski signifikan masih terlalu kecil untuk itu perlu dikaji dan diteliti lebih lanjut variabel lain diluar dari model yang diteliti saat ini

Berdasarkan kesimpulan di atas maka dapat diajukan saran-aran sebagai berikut:

1. Pengendalian dalam prosedur pencairan dana hendaknya ditingkatkan atau lebih dioptimalkan lagi.

2. Setiap pelaksanaan pekerjaan harus sesuai dengan prosedur kerja yang telah ditetapkan dan pimpinan harus selalu mengupdate setiap informasi bila terdapat perubahan.

3. Pimpinan pada masing-masing satuan kerja hendaknya mempertahankan dan meningkatkan kompetensi dengan mengikutsertakan pelatihan-pelatihan dan pendidikan untuk meningkatkan kapasitas para pegawai.

4. Untuk peneliti selanjutnya disarankan untuk meneliti faktor jumlah SDM, jumlah sarana prasarana serta komitmen pada organisasi perangkat daerah.

\section{DAFTAR PUSTAKA}

Akhmad, I., Mustanir, A., \& Ramadhan, M. R. (2017). Pengaruh Pemanfaatan Tekhnologi Informasi Dan Pengawasan Keuangan Daerah Terhadap Kualitas Laporan Keuangan Kabupaten Enrekang. SOSIAL POLITIK \& EKONOMI.

Arfianti. (2011). Analisis faktor-faktor yang mempengaruhi nilai informasi pelaporan keuangan pemerintah daerah (Studi pada satuan kerja perangkat daerah di kabupaten Batang). Universitas Diponegoro.

Blegur, R., Irianto, G., \& Rosidi, R. (2017). Analisis Pelaksanaan Tindak Lanjut Rekomendasi BPK dari Perspektif Teori Edwards III (Kasus pada Kabupaten X di NTT). Jurnal IImiah Administrasi Publik, 3(1), 62-69.

Bustan. (2007). Konsentrasi Manajemen Sumber Daya Manusia (Perencanaan Sumber Daya Manusia, Evaluasi Kerja, Budaya Organisasi). Program Pascasarjana STIE Mahardhika Surabaya-Cetakan Pertama, April 2007 ....

Daga, R., \& Renaldy, R. (2019). Faktor yang mempengaruhi terjadinya retur surat perintah pencairan dana (Studi Kasus Pada Kantor Pelayanan Perbendaharaan Negara 
Makassar I). Jurnal Mirai Management, 4(2), 243-262.

Ghozali, I. (2006). Aplikasi Analisis Multivariate dengan Program IBM SPSS 21 :Update PLS Regresi. Semarang. https://doi.org/10.2307/1579941

Hanafiah, R. R., Abdullah, S. A. S., \& Saputra, M. (2016). Pengaruh Akuntabilitas, Transparansi, Kapasitas Sumber Daya Manusia, dan Pengawasan Intern terhadap Pengelolaan Keuangan Daerah (Studi Di SKPK Pemerintah Kabupaten Aceh Utara). Jurnal Administrasi Akuntansi: Program Pascasarjana Unsyiah, 5(4).

Handoko, T. A. (2013). Manajemen sumber daya manusia. Grasindo.

Haris, A. (2015). Efektivitas Pencairan Dana APBN Dengan Penerapan Sistem

Perbendaharaan Dan Anggaran Negara (SPAN). Universitas Gadjah Mada.

Hartatik, I. P. (2014). Buku Praktis Mengembangkan SDM. Yogyakarta: Laksana.

Hasan. (2002). Analisis validitas dan reliabilitas dengan skala likert terhadap pengembangan si/ti dalam penentuan pengambilan keputusan penerapan strategic planning pada industri garmen (Vol. 15, pp. 155-160).

Hasibuan, B. (2014). VALUASI EKONOMI LINGKUNGAN NILAI GUNAAN LANGSUNG DAN TIDAK LANGSUNG KOMODITAS EKONOMI. Signifikan: Jurnal IImu Ekonomi. https://doi.org/10.15408/sigf.v3i2.2055

Hayadi, F. (2013). Audit Operasional Terhadap Layanan Penerbitan SP2D Non Belanja Pegawai Pada Seksi Pencairan Dana KPPN (Studi Kasus KPPN Malang). Universitas Brawijaya.

Herawati, T. (2014). Pengaruh Sistem Pengendalian Intern Terhadap Kualitas Laporan Keuangan (Survei Pada Organisasi Perangkat Daerah Pemda Cianjur). STAR-Study \& Accounting Research, 11(1), 1-14.

Hood, C. (1991). A Public Mangement For All Saeasons. Public Administration, 69(1), 3-19.

Insani, I. (2010). Pengembangan Kapasitas Sumber Daya Manusia Pemerintah Daerah dalam Rangka Peningkatan Transparansi dan Akuntabilitas Pengelolaan Keuangan Daerah. Jurnal Borneo Administrator, 5(3).

Kapoh, I. T., Karamoy, H., \& Sabijono, H. (2015). Evaluasi Pelaksanaan Sistem dan Prosedur Pengeluaran Kas Uang Persediaan Pada Dinas Pariwisata dan Kebudayaan Kota Manado. Jurnal Riset Ekonomi, Manajemen, Bisnis Dan Akuntansi, 3(1).

Kusumaningsih, M. I. (2016). Analisis Penerapan Standar biaya Penyusunan DPA Dalam Penggangaran Kegiatan Dan Penyusunan Analisis Standar Belanja Pada Pemerintahan Kota Padang. UNIVERSITAS ANDALAS.

Martani, H., \& Lubis, H. (1987). Teori organisasi. Universitas Indonesia.

Mulyadi. (2008). Sistem Akuntansi. Akuntansi.

Nawawi, H. H. (2005). Manajemen Sumber Daya Manusia untuk bisnis yang kompetitif.

Parera, M. T., Kalangi, L., \& Budiarso, N. S. (2019). Sistem pengendalian intern pengeluaran kas pada Sekretariat Daerah Kabupaten Kepulauan Sangihe. Indonesia Accounting Journal, 1(2), 129-136.

Peraturan Menteri Dalam Negeri Nomor 59 Tahun 2007. Tentang Pedoman Pengelolaan Keuangan Daerah.

Ratminto dan winarsih, A. . (2005). Manajemen Pelayanan: Pengembangan Model Konseptual, Penerapan Citizen's Charter dan Standar Pelayanan Minimal.

Salle, A. (2019). Unqualified opinion is not free of corruption: The audit expectation gap in Indonesia. SSRN.

Sedarmayanti. (2012). Good Governance "Kepemerintahan Yang Baik."

Siagian, S. P. (1987). Manajemen Modern. Jakarta: PT. Gunung Agung.

Susanto, A. (2007). Sistem Informasi Manajemen. Undang-Undang Nomor 17 Tahun 2003. 
Tentang Keuangan Negara.

Umar. (2000). Pengaruh Gaya Kepemimpinan terhadap Kinerja dan Kepuasan Kerja Karyawan, 13(4), 39941. 